\title{
Detection of Landscape patterns in airborne LIDAR data in the Nature Reserve of Castelporziano (Rome)
}

\author{
F. Recanatesi, ${ }^{1}$ M. Tolli, ${ }^{2}$ M.N. Ripa, ${ }^{1}$ R. Pelorosso, ${ }^{1}$ F. Gobattoni, ${ }^{1}$ A. Leone \\ ${ }^{1}$ University of Tuscia, Dept. DAFNE, Viterbo, Italy; ${ }^{2}$ Landscape Architect
}

\begin{abstract}
During the last decades the protection of nature has become a very important aspect due to the anthropogenic interference and structural alteration of the environment, especially in the peri-urban areas. Therefore, for a sustainable forest planning it is fundamental to get information about the actual state and the variation in landscape patterns concerning the forest layers. To this aim, an airborne laser scanning (LIDAR), a type of sensor which explicitly measures canopy height, was used to detect landscape patterns of broadleaf oak forest and for detecting the monumental trees in a peri-urban Natural Reserve: the Presidential Estate of Castelporziano (Rome).
\end{abstract}

\section{Introduction}

The Italian landscape has dramatically changed over the last sixty years, a period in which the major transformations that have deconstructed the traditional representations of our country occurred (Lanzani 2003). In this transformation process, coastal environments and especially the coastal peri-urban areas, have shown particular sensitivity (Falcucci and Maiorano 2008; Paolanti et al., 2013), affected by the typical processes of residential expansion and of deep coastal urbanization.

This impoverishment process of natural coastal environments affects the whole Italian territory and in general all of the Mediterranean coastal areas where, for this reason, biodiversity is profoundly threatened.

Correspondence: F. Recanatesi, University of Tuscia, Dept. DAFNE, Via S.Camillo De Lellis, 01100 Viterbo, Italy.

Tel. +39.0761357357 . Fax: +39.0761357453 .

E-mail: fabio.rec@unitus.it ; michela.tolli@gmail.com

Key words: LIDAR, landscape patterns, nature reserve.

Acknowledgements: This study was made possible thanks to the environmental monitoring program for the Estate of castelporziano carried out by the National Academy of Sciences" detta dei XL"(Rome).

(C) Copyright F. Recanatesi et al., 2013

Licensee PAGEPress, Italy

Journal of Agricultural Engineering 2013; XLIV(s2):e94

doi:10.4081/jae.2013.s2.e94

This article is distributed under the terms of the Creative Commons Attribution Noncommercial License (by-nc 3.0) which permits any noncommercial use, distribution, and reproduction in any medium, provided the original author(s) and source are credited.
In these areas, in fact, lowland forest and ancient dune ecosystems are today represented by sporadic and generally very small size fragments (IUCN Europe, European centre for the Cooperation in the Mediterranean areas).

The context of Nature Reserve of Castelporziano effectively represents the process of coastal urbanization that has concerned the entire Italian Mediterranean area (Tolli \& Recanatesi, 2013), in fact, the area near the district Castelporziano-Capocotta-Castelfusano has been affected by the city development model called spontaneous, that is governed only by the laws of the land market and already widely evident in the second half of the " 50 s. This was later accentuated by the " 62 Plan of Rome which has directed most of the urban growth along the sea road director (Marcelloni, 2003). The new urban forecasts do not differ from this trend, providing links to the highway Rome-Latina with a section near the border of the Estate and new residential areas in the Infernetto district and along the Pontine coast.

The process of urbanization has inevitably led to a landscape depleted in its environmental and landscape quality. From a recent study about the ecological relationships between the Nature Reserve of Castelporziano and its territorial context, it is apparent that the Reserve of Castelporziano is the only large area characterized by a prevalence of high and very high environmental quality areas, while everything that is in the immediate context, outside of its administrative boundaries, is mainly defined by low and very low values (Paolanti et al. 2013).

It is evident that the Nature Reserve of Castelporziano, with its 6.000 hectares, mainly covered by oak forests with a high density of monumental trees, with a presence of historical and cultural evidences ranging from Roman times to the Renaissance, with significant elements from XIX Century (Giordano et al., 2006), located near the coast and only $20 \mathrm{~km}$ South of the urban area of Rome, represents a unique place, both for the environmental role, but also for the scenic charm that these historical and natural stratifications can arouse.

All landscapes are a reflection of an organization of space, a way of every object to organize and order themselves in the territory (Turri 1998). Identify patterns in a particular landscape is equivalent to understand the law that regulates its organization (Morris, 1954, Arnheim 1974). Also according to the Landscape Ecology, every type of landscape can be referred to a template, or a pattern, that varies with the structural aspect of the elementary units, or patches, which compose it. Only by recognizing these patterns and then analyzing scientifically, you may be able to give an unsterile planning policies, in the interests of the protection and enhancement (Forman 1986; Farina, 2002).

In the environment of the Nature Reserve of Castelporziano the detection of landscape pattern is really difficult, mainly for the typical conformation of Mediterranean ecosystems where the multi-specificity and layering structure is difficult to understand if not with field surveys. The mixed oak forests are the most frequent and abundant ecosystems in the Reserve (over $4.000 \mathrm{ha}$ ), characterized by extremely variable structure due to the different soil conditions, water availability, upheavals of the urban context (first of all rehabilitation work of the $30 \mathrm{~s}$ ), and the different management over time. There are areas 
where the presence of centuries-old individuals, with heights and impressive size of the canopy and brainstem, are evidence of adaptation to an environment that has remained unchanged over time, while in other areas, the control of the Tiber and the impressive reclamation works have led to a slow replacement of deciduous oaks that once dominated the landscape, with those evergreens, more frugal in terms of edaphic and water needs, (Giordano et al. 2006). As well as a differentiation of the botanical forests species, also the structural aspect is very variable, in fact there is an alternation of areas with a high density of individual trees of different ages, with areas where the tree cover thins considerably to give more space to open areas of bush and grassland. Another important variant is the alternation of areas where the undergrowth is almost absent with areas where it becomes more dense and rich, represented by a dominated layer not too different from the dominant layer in height and size of the crown. Therefore the Reserve landscape is very varied and complex, consisting of layers that require targeted and careful management. Achieve a so difficult goal is not possible without a detailed knowledge of the structural and compositional aspects of the place. Often is very difficult to obtain a detailed knowledge if not through the direct reliefs on site, especially in Mediterranean areas in which the millennial man action is added to a complexity of natural ecosystems.

Currently the ability to make direct measurements on areas of relevant dimensions as those of the Castelporziano Reserve, is increasingly remote due to the costs and the time required, for these reasons we rely more and more often to the Remote Sensing technology (Fuller et al. 1998, Roberts et al. 1998, Cho 2009b). The most common method of detection in Remote Sensing is based on the interpretation of aerial images that have been recorded in this area since the 30s. However, a limiting factor in this type of analysis consists in the lack of visibility of the dominated forest structure, this involves difficulties in the relief of different landscapes pattern. This limitation is particularly relevant for natural Mediterranean environment, but today can be overcome through the use of active sensors such as the latest technology LIDAR (Light Detection and Ranging) that today represents the only way to return dendrometric data relating to the distribution and the vertical structure of the forest (Lefsky et al. 2005; Levick et al., 2009; Rahman \& Gorte 2009; Wessels et al., 2011; Cho et al., 2012; Levick \& Asner 2013).

Therefore, the aim of this paper is to identify the different landscape patterns for the oaks forest, furthermore an additional information concerning the census of monumental trees was obtained by processing data aquired from LiDAR and applying an algorithm to extrapolate them. This process is a key requirement for characterizing landscape pattern (Andersen et sl., 2005, Koch, 2006).

\section{Materials and Methods}

\section{The study site}

The study area is of great historic interest. From the $5^{\text {th }}$ century onwards it was a possession of the Vatican State, until the $19^{\text {th }}$ century, when it was established as a hunting reserve for the Italian Royal Family. Finally, at the end of the Second World War, Castelporziano was chosen as the presidential estate of the Italian Republic, thanks to its rich environmental and cultural heritage

The Presidential estate of Castelporziano, within the territory of Castelporziano and Capocotta, was established as a State nature reserve in the 1999. It covers over about 6000 ha, extending SouthSouth West of Rome (20 km from the city) towards the Tyrrhenian sea (Figure 1). Inside the nature reserve there are two Site of Community Importance (SCI): the coastal area (IT6030027) and the lowland oak

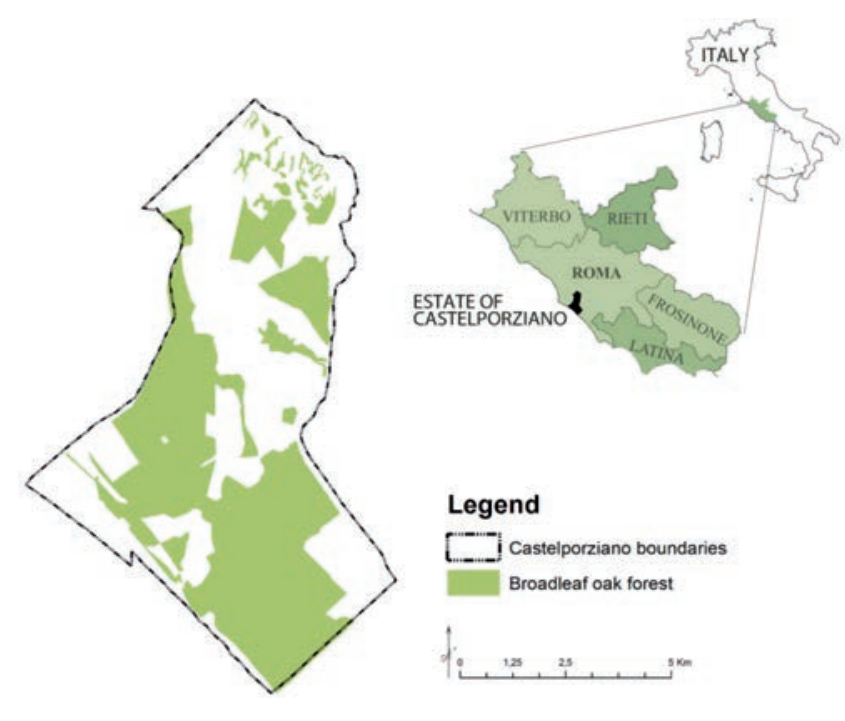

Figure 1. Location of the study area.

woodland (IT6030028). This area, including neighbouring territory of Castelfusano, is what remains of the forest system which once covered the delta of the River Tiber and its neighbouring zones.

The area of the Castelporziano Estate is between 0 and $85 \mathrm{~m}$ (a.m.s.l.) and it is mainly flat with a mean slope of 5\% to the sea. The climate is meso-Mediterranean with a hot and dry period between May and August and precipitations peaks in spring and autumn, the annual average rainfall is approximately $750 \mathrm{~mm}$. Geo-morphologically, the Estate is divided into two parts: the oldest one (Late Pleistocene) is the Ancient Dune (4/5 of the territory) in northern sector and the newest one (Holocene: 10.000 years ago) is the New Dune near the coast in the southern part.

The type of vegetation was once very common but has now almost disappeared not only in the territory of Rome, but also on many Mediterranean coasts. The territory remained substantially unchanged over the last centuries, allowing an undisturbed growth of the vegetation, which was able to develop and mature considerably. Castelporziano can be considered a unique environment in the Mediterranean due to the concentration of very old plants (Quercus cerris L., Quercus pubescens Willd., Quercus robur L.) which, in consideration of their age and size (many are more then 400 years), can be defined as "monumental trees" (Pignatti et al., 2001; Giordano et al., 2006).

\section{Characteristics of Lidar data set}

In this study we used LiDAR data, an active sensor that emits laser pulses and measures the return time for each beam to travel between the sensor and a target using ultra-accurate clocks. The location of every laser return within a coordinate system is achieved by precise kinematic positioning using differential GPS and orientation parameters obtained by an inertial measurement unit (IMU). The IMU captures orientation parameters of the scanner such as roll, pitch and heading angles. Thus, the GPS provides the coordinates of the laser source and the IMU the direction of the pulse. With the ranging data accurately measured and time-tagged by the clock, the position in the horizontal and vertical planes of the return pulses can be calculated. Data are captured as the aircraft moves forward, a scanning mirror directs laser pulses back and forth across the flight line. As a result, the data are spatially distributed as a sawtooth arrangement of points. The majority of the commercial sys- 
tems can collect between 20.000 and 75.000 records per second and the LiDAR data sets are normally distributed as large point files in an ASCII XYZ format. Data point density depends on the number of pulses transmitted per unit time, the scan angle of the instrument, the elevation of the aircraft above ground level, and the forward speed of the aircraft. The system is capable of achieving high vertical and horizontal accuracies. This may vary between 15 and $20 \mathrm{~cm}$ RMS vertically, while horizontal accuracies are about $20-30 \mathrm{~cm}$. For this study we used data detected in June 2010 with a resolution of $1 \mathrm{~m}$.

\section{Landscape pattern}

The location of forest stands characterized by deciduous oak forest has been detected through the woodcut paper on the occasion of Forest Management Plan (FMP) (Giordano et al., 2006).

The determination of the landscape pattern was performed by referring to the definition of Forman \& Godron (1986) in which "... the landscapes are systems of environmental systems that exist at the scale of kilometers and include recognizable elements, related to types of ecosystems and human settlements and / or other manmade elements ... ". In the natural environments present in Castelporziano, characterized by oak forests (2.890 ha), the detection of the different landscape patterns has been performed by a classification of the territory finalized to the identification of two basic components:

1. The analysis of the spatial structure of forest stands with a predominance of broadleaf oaks;

2. The census of all trees with dendrometric characteristics of monumentality.

With regard to the structure of forest stands, in the present study, this refers to the spatial distribution of plants and their membership in the different layers of the forest (dominant layer and dominated layer) and the type of management (coppice and high forest).

Given the high historical environmental component of these stands was also conducted an investigation to determine the number and spatial distribution of the plants that, by extension of the crown and to the size dendrometric reached, can be considered as monumental trees as provided by current legislation LR n. 39 28/10 2002.

The census of all plants monumental and their spatial distribution have allowed an implementation of the state of knowledge concerning the landscape features of the area in question.

The detection of landscape patterns for broadleaf forest oak was obtained using LIDAR data. These data were employed to analyze the forest layers by means of horizontal sections, detected at different heights from the ground. To this aim we have been consulted data collected in the field related to the heights for different forest layers. (Means et al., 1999; Andersen et al., 2005; Angelo et al., 2010; Giordano et al., 2010; Eysn et al., 2012).

\section{The census of monumental trees}

We used ArcMap software in processing LIDAR data. A raindrop algorithm is used to estimate both tree tops and corresponding "light crown boundaries" in the DSM (Suarez et al., 2005; Koch et al., 2006). The algorithm assumes the input data describing a "mountain range". Firstly the local maxima are calculated, pixel that present larger values than their 4 connective neighbors are marked as maxima. Secondly, starting from these maxima an expansion is done until the valley bottoms are reached, like raindrops running downhill in all possible direction. This part of the algorithm continues as long as the examined points found are smaller or equal.

Once got the perimeter, and then the surfaces of the crowns of all the trees, was performed Reclass to isolate all the plants with a surface of the crown equal to or greater than $110 \mathrm{~m} 2$. This value has been identified by the consultation of the data collected in sample plots.

\section{Data field}

Information regarding the heights of the different layers that characterize the different types of forest were obtained from geo-referenced data, collected in 53 sample plots (30 m radius), carried out during the updating of the Forest Management Plan, 2010 (Giordano et al., 2013). In the sample plots were recorded classical dendrometric parameters: forest structure, species composition; heights of forest layers; management system and plant density. In the sample plots the census of monumental trees present are also reported. These data concerning the surface of the crown coverage and their location in the territory have been used in the validation of the results obtained from the raindrop algorithm analysis of LIDAR data.

\section{Results}

The analysis of LIDAR data allowed the determination of four landscape patterns, of which follows a brief description about their structure and considerations regarding the perceptual analysis. Figure 2 shows the inherent thematic mapping of their distribution in the Estate of Castelporziano:

1. Natural coastal landscape (NCL);

2. Anthropogenic trasformation landscape (ATL);

3. Changing coastal plain landscape (CCPL);

4. Stable lowland ancient oak landscape (SLAOL).

\section{Natural coastal landscape}

Landscape composed of dune ridges semi stabilized or stabilized by intercropping endemic flora characterized by juniper (Juniperus oxycedrus) with a prevalence of low mediterranean macchia characterized by heather and phillyrea. The innermost part of the territory, for this class of landscape, is characterized by stabilized dune ridges, with maquis and holm oak, and depressions interdunal. From a perceptual point of view this landscape has a twofold component, the first is a low bush, where the trees never grow to over one meter and a half, an

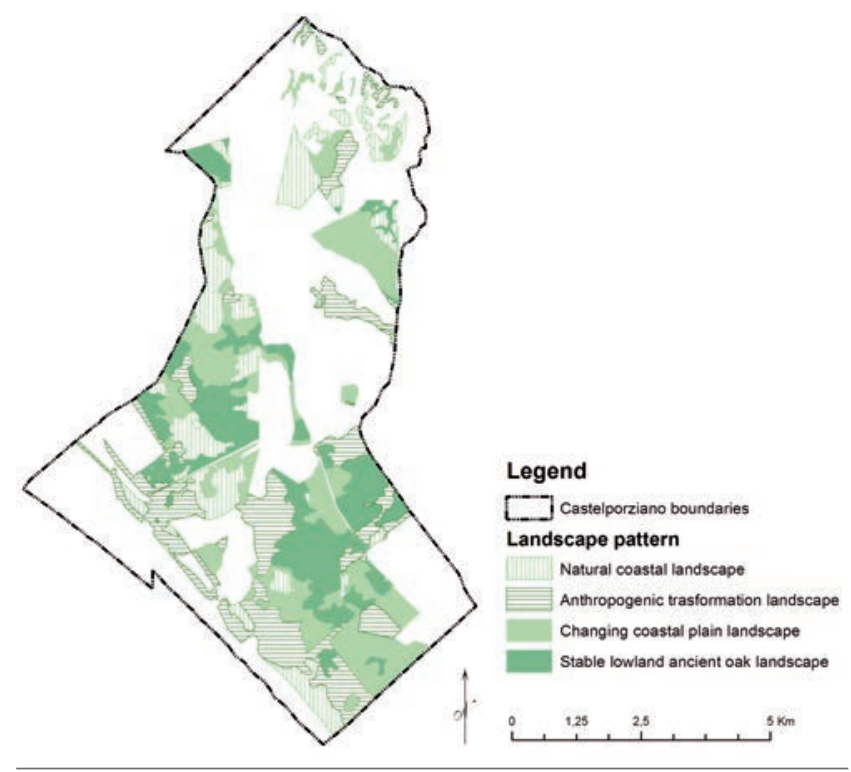

Figure 2. Landscape Pattern detected and localization of sample areas (black dots). 
aspect that allows an overview with extensive visual framing the pattern in its context, and the second one is a spot more than two meters high and impenetrable that arises then as a barrier perception.

\section{Anthropogenic transformation landscape}

Landscape pertaining to the flood plain behind the dunes in which are obvious effects of land management aimed at the exploitation of forest resources it has, over the centuries, changed the original natural structure of the forest. The effects of such a harvesting have resulted in the depletion in the number of plant species of trees and a simplification of the vertical structure of the same. The selective cuts, perpetrated until the $80 \mathrm{~s}$, at regular intervals (for these kind of coppice the rotation was established in 18 years) have shaped the forest structure whose effects, in terms of ecosystem, are due to the simplification of the landscape reduced to a single layer with a predominance of an unique arboreal species. In some areas it was found a plan dominated by shrub consists of a high spot in the prevalence of heather and phillyrea. Because of the abundance of suckers, given the rigid cycles of use followed in the past, this landscape is perceived as an element that is free of visual cones that allow the perception of the internal structure and a contextualization with the surrounding landscape

\section{Changing coastal plain landscape}

Landscape represented by all those forest that were excluded from harvesting programs and that, for this reason, today appear in an intermediate evolutionary stage between a management characterized by coppice and the stable formation represented from lowland oak. In this class of landscape stand still signs of coppicing, interrupted over 60 years ago, that has led to an increasing age of the stumps with the consequent self selection of the suckers. Forest ecosystems begin to present the characteristics of vertical diversification with the intrusion of accompanying species such as hornbeam, and occasionally the maple tree which presents heights dendrometric between the high spot and the deciduous oak forest. This structure makes it very varied the visual perception, in fact, it passes from areas in which the forest layer is very fraught, and it behave as a visual screen, with the other in which the visual perception dilates in open areas as visual cones that, in this way, allows the perception the complex stratification that characterizes it.

\section{Stable lowland ancient oak landscape}

Stable landscape, characterized by the presence of oaks with senescent characteristics and dendrometric monumentality. These environments have more characters of stability as they have reached a climax status. From a perceptual point of view this is a landscape pattern extremely interesting for its characterization, in fact there are alternation of full and empty that determine open visual spaces and a depth field always variables.
Figure 3 shows a schematic diagram of the landscape patterns detected, where, from the calculations of the LIDAR data, the vertical structures emerge for each type of landscape detected. On the patterns SLAOLA and CCPL, by way of example, have been superimposed information pertaining to the census of monumental trees detected by the raindrop algorithm used. These information has also allowed a spatial representation of the forest area in the three dimensions allowing a classification of the entire territory in landscape structures.

It was also quantified, Figure 4, at the scale of landscape pattern, the functionality in terms of: stability, naturalness, complexity and vulnerability. This representation was carried out with purely subjective criteria, and has the simple purpose of comparing the patterns detected.

The geo-referenced data regarding the number, size and shape of the patches for individual landscape patterns have been developed for the determination of the main indices of the metric own of the landscape metrics.

In Table 1, we report the values distributed according to the four patterns identified. The most significant data indicate a high degree of fragmentation observed on all patterns, this data determine, as a result, an average size of the patch somewhat reduced. Significant also appear the results obtained for the edge metrics, where the values inherent in the edge density expressed per hectare, show an irregular spatial distribution of patches of different patterns. The shape metrics, finally,

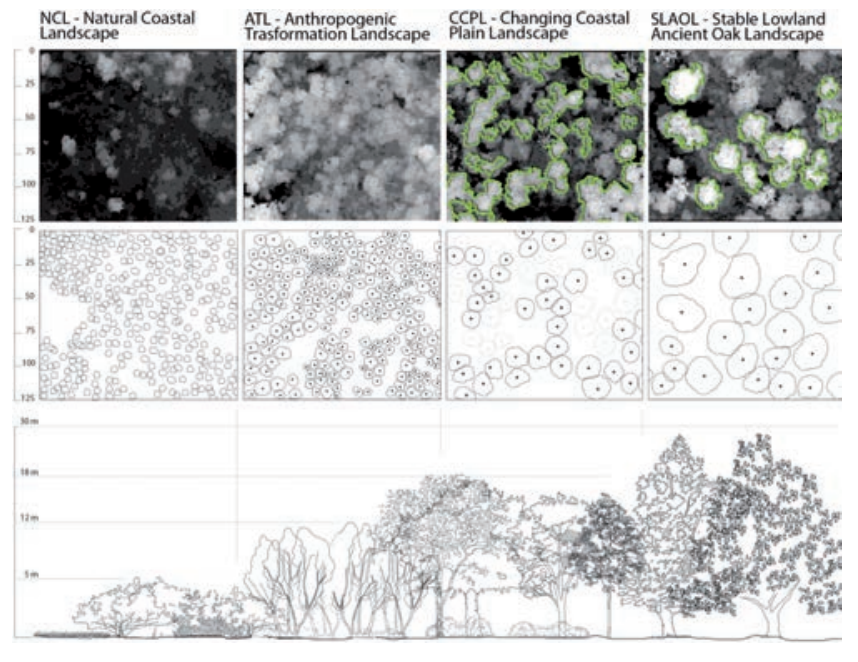

Figure 3. Conceptual framework on the census of landscape pattern in the Estate of Castelporzianothe. The green lines show the detection of monumental trees obtained by LIDAR data for CCPL and SLAOL landscapes.

Table 1. Landscape indices for landscape patterns.

\begin{tabular}{|c|c|c|c|c|c|c|c|c|c|}
\hline \multirow[b]{2}{*}{ Landscape Pattern } & \multicolumn{4}{|c|}{ Patch Density \& Size Metrics } & \multicolumn{2}{|c|}{ Edge metrics } & \multicolumn{3}{|c|}{ Shape metrics } \\
\hline & Surface (ha) & $\begin{array}{c}\text { Number of } \\
\text { Patches }\end{array}$ & $\begin{array}{c}\text { Mean Patch } \\
\text { Size }\end{array}$ & $\begin{array}{c}\text { Median } \\
\text { Patch Size }\end{array}$ & $\begin{array}{l}\text { Total } \\
\text { Edge } \\
(\mathrm{m})\end{array}$ & $\begin{array}{c}\text { Edge } \\
\text { Density } \\
(\mathrm{m})\end{array}$ & MSI & AWMSI & $\begin{array}{c}\text { Mean } \\
\text { Perimeter- } \\
\text { Area ratio }\end{array}$ \\
\hline Natural Coastal Landscape & 574,1 & 42,0 & 13,7 & 5,4 & 72258,4 & 25,0 & 1,6 & 1,9 & 7294,1 \\
\hline Anthropogenic Transformation Landscape & 741,1 & 22,0 & 33,7 & 10,2 & 90309,1 & 31,2 & 2,1 & 3,0 & 247,6 \\
\hline Changing Coastal Plain Landscape & 871,5 & 34,0 & 25,6 & 10,7 & 90472,1 & 31,3 & 1,7 & 2,0 & 1915,9 \\
\hline Stable Lowland Ancient Oak Landscape & 705,1 & 23,0 & 30,7 & 11,8 & 69596,2 & 24,1 & 1,9 & 2,3 & 1266,5 \\
\hline
\end{tabular}


shows the above in terms of spatial distribution and irregular shapes.

With regard to the census of monumental trees, in the study area were surveyed a total of 412 trees with a surface of the crown that can be considered monumental $\left(>110 \mathrm{~m}^{2}\right)$. Compared to field data concerning the crown coverage of monumental trees the method presented delivers a $\mathrm{K}$ of 0.8 for the study area, Figure 5 .

\section{Conclusions}

The determination of landscape pattern plays a key role in the identification and management of multifunctionality and externalities that a protected area such as peri-urban Nature Reserve Castelporziano is able to express.

To this aim, the use of LIDAR data proved to be a versatile and effective tool above all considering the geographical location of the study area falling in the Mediterranean environment. The ability to analyze the forest area in terms of its vertical structure allows you to compensate for the limitations of the usual remote sensing instruments (photo interpretation and/or images obtained from satellite platforms) that do not allow investigations below the plane of the dominant topsoil thus making it necessary inspections in the field with inevitable repercussions on the execution times and costs.

With regard to the census of woody plants monumental, the high-resolution LIDAR data, together with the use of the raindrop algorithm, present in the suite of ArcMap have provided a comprehensive census of the plants monumental in size and number.

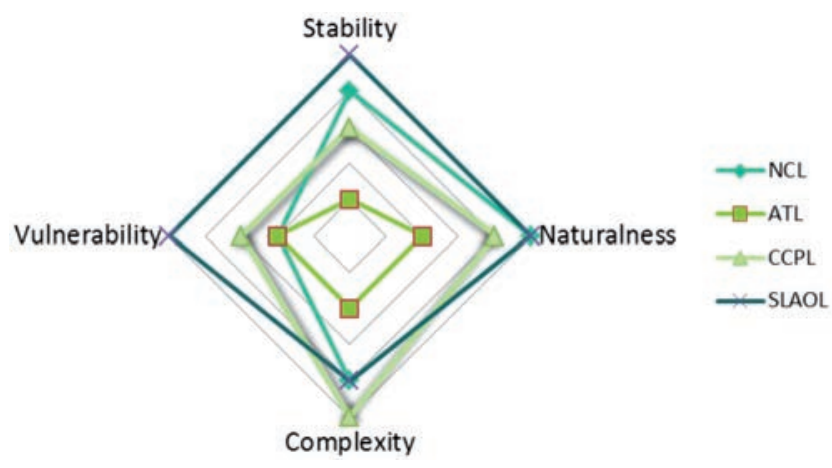

Figure 4. Functionality of the landscape patterns detected.

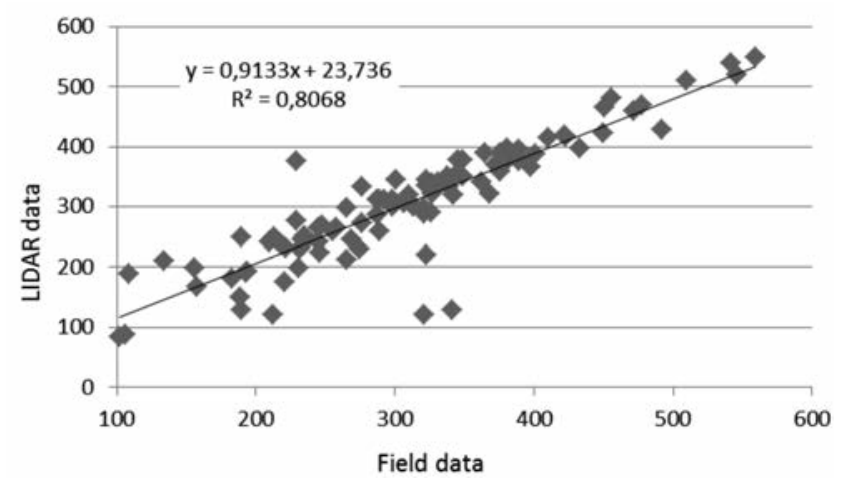

Figure 5. comparison between LIDAR and field sample data in crown coverage detection for monumental trees.

\section{References}

Andersen H, McGaughey R, reutebuch S. 2005. Estimatig forest canopy fuel parameters using LIDAR data. Remote Sensing of Environment. Vol. 94, pp. 441 - 449

Arnheim R, 1974. Il pensiero visivo. La percezione come attività conoscitiva. Einaudi (T0)

Angelo J, Duncan B, Weishampel J. 2010. Using LIDAR derived vegetation profiles to predict time since fire in an oak scrub landscape in East central Florida. Remote sensing. Vol. 2, pp. $514-525$

Eysn L, Hollaus M, Schadauer K, Pfeifer N. 2012. Forest Delineation Based on airborne LIDAR data. Remote Sensing. Vol. 4, pp. 762 783

Falcucci A, Maiorano L, 2008. Uso ed abuso del suolo: la trasformazione del paesaggio in Italia dal 1950 ad oggi. In: Riconquistare il paesaggio. La Convenzione Europea del Paesaggio e la Conservazione della Biodiversità in Italia. MIUR.

Gazzetta Ufficiale della Repubblica Italiana. Legge Regionale n. 39 del 28 ottobre 2002.

Giordano E, Maffei L, , Recanatesi F, Tinelli A. 2013. Aggiornamento del Piano di Gestione Forestale per i boschi della Tenuta Presidenziale di Castelporziano. In: Il Sistema Ambientale della tenuta Presidenziale di Castelporziano (Roma). Accademia Nazionale delle Scienze detta dei XL. Scritti e documenti.

Giordano E, Capitoni B, Eberle A, Maffei L, Musicanti A, Recanatesi F, Torri V. 2006. Proposta per il piano di gestione forestale della tenuta presidenziale di Castelporziano. In: Il Sistema Ambientale della Tenuta Presidenziale di Castelporziano - ricerche sulla complessità di un ecosistema forestale costiero mediterraneo. Accademia Nazionale delle Scienze detta di XL.

Falcucci A, Maiorano L, 2008. Uso ed abuso del suolo: la trasformazione del paesaggio in Italia dal 1950 ad oggi. In: Riconquistare il paesaggio. La Convenzione Europea del Paesaggio e la Conservazione della Biodiversità in Italia. MIUR.

Farina A, 2002. Ecologia del paesaggio. Principi metodi e applicazioni. UTET Università.

Forman R T, Gordon M. 1986. Landscape Ecology. Springer-Verlag, (NY).

Fuller et al. 1998. The integration of field survey and remote sensing for biodiversity assessment: A case study in the tropical forests and wetlands of Sango bay, Uganda. Biological Conservation, 86(3), pp. 379-391.

Koch B, Heyder U, Weinacker H. 2006. Detection of individual tree crowns in airborne LIDAR data. Photogrammetric Engineering \& Remote sensing. Vol. 72, n. 4, pp. $357-363$

Lanzani A., 2003. I paesaggi italiani. Maltemi editore ( $\mathrm{Rm})$

Levick S, Asner G. 2013. The rate and spatial pattern of tree fall in a savanna landscape. Biological Conservation. Vol. 157, pp. 121 - 127

Marcelloni M., 2003. Pensare la città contemporanea. Il nuovo piano regolatore di Roma. Editori LaTerza (Roma-Bari)

Means J, Acker S, Harding D, Blair J, Lefsky M, Cohen W, Harmon M, McKee A. 1999. Use of large-Footprint scanning airborne LIDAR to estimate forest stand characteristics in the western cascades of Oregon. Remote Sensing Envoronment. Vol. 67, pp. 298 - 308

Morris Ch, 1954. Lineamenti di una teoria dei segni. Paravia (T0)

Paolanti M, Blasi C, 2013. Valutazione delle relazioni ecologiche e degli impatti tra la Tenuta di Castelporziano e il suo contesto territoriale. In: Il sistema ambientale della Tenuta Presidenziale di Castelporziano (Rm). Accademia Nazionale delle Scienze detta dei $X L$. Scritti e documenti.

Rahman M, Gorte B. In: Laser scanning. Vosselman G (Eds). IAPRS, Vol. XXXVIII. Paris, 2009

Suarez J, Ontiveros C, Smith S, Snape S. 2005. Use of airborne LIDAR 
and aerial photography in the estimation of individual tree heights in forestry. Computer \& Geoscience. Vol. 31, pp. $253-262$

Turri E., 1998. Il paesaggio come teatro. Dal territorio vissuto al territorio rappresentato. Marsilio Editore (VE)

Tolli M, Recanatesi F. 2013. Variation in landscape patterns and vegetation cover between 1930 and 2010 in a coastal Mediterranean natural reserve. Conference Uniscape: Landscape \& Imagination, Paris 2-4 may. 